\title{
Carbon coated magnetic nanoparticles as supports in microwave-assisted palladium catalyzed Suzuki-Miyaura couplings
}

\author{
Sebastian Wittmann', Jean-Pierre Majoral' ${ }^{2}$, \\ Robert N. Grass ${ }^{3}$, Wendelin J. Stark ${ }^{3}$ \\ and Oliver Reiser ${ }^{1, *}$ \\ ${ }^{1}$ Institute of Organic Chemistry, University of Regensburg, \\ 93053 Regensburg, Germany, \\ e-mail: Oliver.Reiser@chemie.uni-regensburg.de \\ ${ }^{2}$ CNRS Coordination Chemistry Laboratory, 205 route de \\ Narbonne, 31077 Toulouse cedex 4, France \\ ${ }^{3}$ Institute of Chemical and Bioengineering, Department \\ of Chemistry and Applied Biosciences, ETH Zürich, \\ Wolfgang-Pauli-Strasse 10, 8093 Zürich, Switzerland \\ *Corresponding author
}

\begin{abstract}
A palladium bis- $N$-heterocyclic carbene complex was immobilized on polystyrene modified, magnetic carbon coated iron nanoparticles and evaluated in Suzuki-Miyaura cross-coupling reactions under conventional and microwave heating. Under the latter conditions, both aryl bromides and aryl chlorides could be employed as substrates at low loading of catalyst $(0.2 \mathrm{~mol} \%)$, which could be readily recovered by an external magnet and reused in at least four cycles. As a possible deactivation pathway of the catalyst, the formation of palladium nanoparticles in the course of the reaction that became encapsulated in the polystyrene matrix of the support is suggested.
\end{abstract}

Keywords: magnetic nanoparticles; microwave irradiation; palladium- $N$-heterocyclic carbene catalysts; recyclable catalyst; Suzuki-Miyaura coupling.

\section{Introduction}

The development of efficient catalytic processes is an important quest in sustainable chemistry. Reactivity, as expressed in turnover numbers and cycles of a catalyst, selectivity as well as low energy consumption are criteria to strive towards this goal. The immobilization of catalysts on heterogeneous supports is a widely employed strategy to increase turnover numbers by allowing facile recycling and reuse of the catalyst [1]. Nevertheless, employing conventional polymers as supports is often accompanied by reduced activity of catalysts due to inaccessibility of active sites being buried in the polymer backbone and reduced mass transfer due to heterogenization. Moreover, the mechanical properties of polymer supports are not always optimal, which can lead to their degradation in the course of handling a reaction mixture by stirring or filtration procedures. Magnetic nanoparticles have been recognized as attractive supports for catalysts owing to their good surface accessibility and facile recovery by applying an external magnetic field [2-4]. In particular, carbon coated iron and cobalt nanoparticles have been found to display especially high thermal stability as well as tolerance against basic or acidic reaction conditions [5-11]. We therefore wanted to combine such nanoparticles with a highly stable metal complex to arrive at recyclable catalysts that might be suitable for their utilization under forcing thermal conditions. Palladium- $N$-heterocyclic carbene (NHC) complexes in particular exhibit high stability against heat, moisture and air [12]. As a suitable benchmark we were intrigued by recent studies demonstrating that complexes such as $\mathbf{1}$ or $\mathbf{2}$ (Figure 1) are highly stable and show good activity in cross-coupling and Heck reactions with aryl bromides but not with aryl chlorides [13-15].

\section{Experimental}

\subsection{General}

Microwave experiments were carried out in a CEM Discover ${ }^{\circledR}$ S-Class apparatus, inductively coupled plasma optical emission spectrometry (ICP-OES) measurements were performed with Spectro Analytical Instruments ICP Modula EOP and transmission electron spectroscopy (TEM) measurements with LEO912AB electron microscope (Zeiss, Oberkochen, Germany) operating at $100 \mathrm{kV}$.

\subsection{3,3'-(5-Hydroxy-1,3-phenylene)bis(methylene) bis(1-mesityl-1H-imidazol-3-ium) bromide (5)}

Seven hundred and eleven milligram (2.54 mmol) 3,5bis(bromomethyl)phenol (3) [16] and $946 \mathrm{mg}$ (5.08 mg, 2.0 equiv.) 1-mesityl-1H-imidazole (4) [17] were stirred in $5 \mathrm{ml}$ $\mathrm{MeCN}$ at $90^{\circ} \mathrm{C}$ in a sealed tube for $1 \mathrm{~h}$. After cooling down to ambient temperature the white precipitate was washed thrice with $\mathrm{MeCN}$ and acetone to yield $1.42 \mathrm{~g}(2.2 \mathrm{mmol}, 86 \%) \mathbf{5}$ as a white solid. ${ }^{1} \mathrm{H}-\mathrm{NMR}$ (300 MHz, DMSO): $\delta=10.01(\mathrm{~s}, 1 \mathrm{H})$, $9.71(\mathrm{~s}, 2 \mathrm{H}), 8.11(\mathrm{~s}, 2 \mathrm{H}), 8.00(\mathrm{~s}, 2 \mathrm{H}), 7.15(\mathrm{~s}, 4 \mathrm{H}), 7.07(\mathrm{~s}, 1 \mathrm{H})$, $6.84(\mathrm{~s}, 2 \mathrm{H}), 5.52(\mathrm{~s}, 4 \mathrm{H}), 2.33(\mathrm{~s}, 6 \mathrm{H}), 2.01(\mathrm{~s}, 12 \mathrm{H}) ;{ }^{13} \mathrm{C}-\mathrm{NMR}$ (75 MHz, DMSO): $\delta=158.3,140.2,137.6,136.7,134.1,131.0$, $129.2,124.1,123.2,118.4,115.2,108.4,51.9,20.5,16.9$; IR (neat) $v=3387,3061,1703,1601,1557,1497,1456,1355,1310$, 1231, 1147, 1107, 1030, 1009, 876, 749, 714, 698, 663; MS (EI): $\mathrm{m} / \mathrm{z}=246.0\left(\mathrm{M}^{2+}\right)$; HRMS (EIMS) $\left[\mathrm{M}^{2+}\right]$ : found 246.1450, calculated 246.1439; m.p.: $145^{\circ} \mathrm{C}$ (decomposition). 


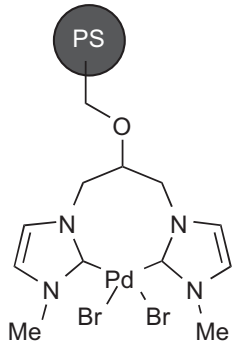

1

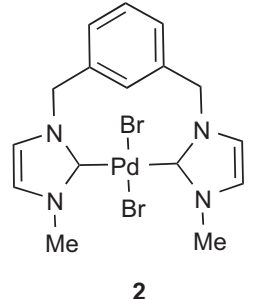

Figure 1 Successful bis-NHC-palladium complexes for SuzukiMiyaura couplings of aryl bromides [12-14].

\section{3. (3,3'-(5-Hydroxy-1,3-phenylene)bis(methylene) bis(1-mesityl-1H-imidazolium-2,2'-diyliden)) palladium(II)-dichloride (7)}

To $250 \mathrm{mg}(0.38 \mathrm{mmol})$ of $(\mathbf{5})$ in $10 \mathrm{ml}$ dichloromethane (DCM), $98 \mathrm{mg}$ (0.42 mmol, 1.1 equiv.) of $\mathrm{Ag}_{2} \mathrm{O}$ were added. The slurry was stirred for $4 \mathrm{~h}$ under the exclusion of light. Subsequent filtration through a syringe filter and evaporation of the solvent furnished $\mathbf{6}$ as a white powder, which was used as such in the next step. 6 was dissolved in $10 \mathrm{ml}$ of degassed dichloromethane followed by addition of 110 mg $(0.38 \mathrm{mmol})$ of $\mathrm{PdCl}_{2}(\mathrm{cod})$, and the reaction mixture was stirred for $16 \mathrm{~h}$. Filtration through a syringe filter and subsequent evaporation of the solvent furnished a yellow powder which was purified by precipitation from a saturated dichloromethane solution with pentane. Centrifugation of the precipitate and subsequent recrystallization from $\mathrm{CHCl}_{3}$ gave $219 \mathrm{mg}(0.33 \mathrm{mmol}, 86 \%)$ of 7 as amorphous yellow platelets. ${ }^{1} \mathrm{H}-\mathrm{NMR}(300 \mathrm{MHz}, \mathrm{DMSO}): \delta=7.35-6.93(\mathrm{~m}$, br, 5H), 6.93-6.41 (m, br, 7H), 5.80-5.39 (m, br, 2H), 5.24 (m, br, 2H), 2.43 (m, br, 3H), 2.30 (m, br, 1H), 2.08 (m, br, 5H), 1.97 (m, br, 3H), 1.82 (m, br, 7H); IR (neat) $v=2916$, 1598, 1487, 1448, 1415, 1297, 1233, 1160, 1033, 968, 934, 848, 728, 702; MS (ESMS): $\left[\mathrm{M}^{2+}-2 \mathrm{Cl}^{-}-\mathrm{H}^{+}\right] \mathrm{m} / \mathrm{z}=593.3$, 594.1, 595.2, 597.1, 599.1, 600.1; $\mathrm{CHN}\left(\mathrm{C}_{32} \mathrm{H}_{34} \mathrm{Cl}_{2} \mathrm{~N}_{4} \mathrm{OPd}\right)$ : calculated: C 57.54, H 5.13, N 8.39, found: C 58.12, H 5.37, N 7.26; m.p.: $>200^{\circ} \mathrm{C}$ (decomposition).

\subsection{Synthesis of 9 by immobilization of 7 on polystyrene modified, carbon coated iron nanoparticles 8}

To $25 \mathrm{mg}$ (corresponding to $0.095 \mathrm{mmol}$ benzyl chloride functionalities) of 8 in $3 \mathrm{ml}$ DMF were added $70 \mathrm{mg}(0.105$ mmol, 1.1 equiv.) 7 and $30 \mathrm{mg}(0.22 \mathrm{mmol}, 2.0$ equiv. $)$ of $\mathrm{K}_{2} \mathrm{CO}_{3}$. After vigorously stirring at $60^{\circ} \mathrm{C}$ for $18 \mathrm{~h}$, the particles were recovered by the aid of an external magnet and subsequently washed with acetone, water, acetone and dichloromethane. After drying under reduced pressure $37 \mathrm{mg}$ of the particles with a loading of $0.6 \mathrm{mmol} / \mathrm{g}$ (ICP-OES) was obtained. IR (neat) $v=3651,2915,2117,1748,1664,1596$, 1510, 1487, 1448, 1413, 1381, 1357, 1291, 1235, 1151, 1034, $1015,931,847,810,726,700,654$; elemental microanalysis (\%): C, 70.71; H, 4.43; N, 3.92.

\subsection{General procedure for Suzuki-Miyaura cross- coupling reactions with the supported catalyst 9}

A mixture of 9 (3 mg, $0.2 \mathrm{~mol} \%)$, arene R-X (1.0 mmol), boronic acid (1.1 mmol, 1.1 equiv.) and $\mathrm{K}_{2} \mathrm{CO}_{3}$ or $\mathrm{Cs}_{2} \mathrm{CO}_{3}$ (2.0 mmol, 2 equiv.) as detailed in Tables 1 or 2 in toluene $(2 \mathrm{ml})$ was stirred at $70^{\circ} \mathrm{C}$ or heated in a closed microwave vessel at a constant power of $200 \mathrm{~W}$ for the indicated time. The catalyst was retained after the reaction in the vessel by applying an external magnet, the reaction mixture was decanted, and the reaction vessel containing the nanoparticles was washed with toluene, $\mathrm{MeOH}$, water and $\mathrm{MeOH}$ (5 $\mathrm{ml}$ each). The combined organic fractions were extracted with water $(10 \mathrm{ml})$, dried $\left(\mathrm{Na}_{2} \mathrm{SO}_{4}\right)$, filtered, concentrated under reduced pressure and the residues were purified by column chromatography. The recovered catalyst was dried under reduced pressure and subsequently subjected to the next run.

\section{Results and discussion}

To arrive at a suitable magnetic nanoparticle supported ananlog to $\mathbf{2}$, we prepared the palladium complex $\mathbf{7}$ that was attached onto polystyrene modified, carbon coated iron particles (PS@C@Fe-NP, 8) [18] to give the nanocatalyst 9 with a loading of $0.6 \mathrm{mmol} \mathrm{Pd} / \mathrm{g}$ (Scheme 1).

9 was first evaluated in Suzuki cross-couplings applying thermal heating (Table 1). At $0.2 \mathrm{~mol} \%$ catalyst concentration, for a variety of aryl bromides quantitative conversion and high yields in the coupling with phenyl boronic acids was reached within $12 \mathrm{~h} .9$ could be readily recovered by applying an external magnet to the reaction vessel and decantation of the reaction solution and

Table 1 Suzuki-Miyaura reaction catalyzed by 9 under conventional heating conditions $\mathrm{s}^{\mathrm{a}}$.

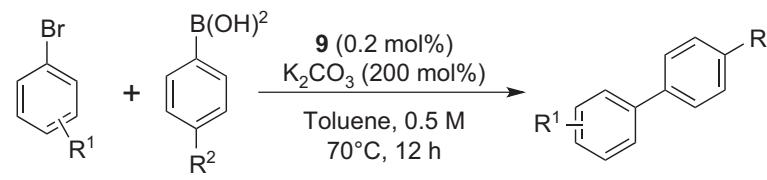

\begin{tabular}{rllll}
\hline Entry & Run & $\mathrm{R}^{1}$ & $\mathrm{R}^{2}$ & Conversion $^{\mathrm{b}}(\%)$ \\
\hline 1 & 1 & $4-\mathrm{OMe}$ & $\mathrm{H}$ & $>95$ \\
2 & 2 & $4-\mathrm{OMe}$ & $\mathrm{H}$ & $>95$ \\
3 & 3 & $4-\mathrm{OMe}$ & $\mathrm{H}$ & $>95$ \\
4 & 4 & $4-\mathrm{OMe}$ & $\mathrm{H}$ & $>95$ \\
5 & 5 & $4-\mathrm{OMe}$ & $\mathrm{H}$ & $>95$ \\
6 & 6 & $4-\mathrm{OMe}$ & $\mathrm{H}$ & $>95$ \\
7 & 1 & $2,6-\mathrm{Me}$ & $\mathrm{H}$ & $61^{\mathrm{c}}$ \\
8 & 2 & $4-\mathrm{NO}_{2}$ & $\mathrm{H}$ & $95^{\mathrm{c}}$ \\
9 & 3 & $4-\mathrm{C}(\mathrm{O}) \mathrm{Me}$ & $\mathrm{H}$ & $93^{\mathrm{c}}$ \\
10 & 4 & $\mathrm{H}$ & $\mathrm{Me}$ & $91^{\mathrm{c}}$ \\
11 & 5 & $4-\mathrm{OMe}$ & $\mathrm{H}$ & $89^{\mathrm{c}}$ \\
\hline
\end{tabular}

aReaction conditions: $0.5 \mathrm{mmol}$ aryl halide, $0.55 \mathrm{mmol}$ arylboronic acid, $1.0 \mathrm{mmol} \mathrm{K} \mathrm{CO}_{3}, 0.2 \mathrm{~mol} \%$ starting concentration of catalyst 9 (series 1, entries 1-6; series 2, entries 7-11), $2 \mathrm{ml}$ toluene, $70^{\circ} \mathrm{C}$, $12 \mathrm{~h}$.

${ }^{b}$ Determined by ${ }^{1} \mathrm{H}-\mathrm{NMR}$.

'Isolated yield after column chromatography. 
Table 2 Suzuki-Miyaura reaction catalyzed by 5 under microwave conditions ${ }^{\mathrm{a}}$.

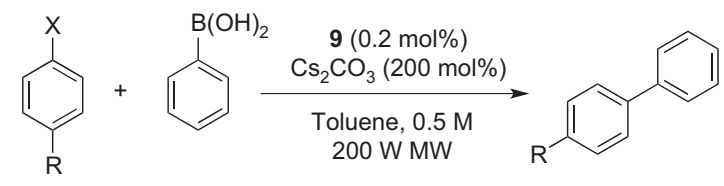

\begin{tabular}{llllcc}
\hline Entry & Cycle & \multicolumn{2}{l}{ Aryl halide } & \multirow{2}{*}{$\begin{array}{c}\text { Time } \\
(\text { min })\end{array}$} & $\begin{array}{l}\text { Yield }^{b} \\
(\%)\end{array}$ \\
\cline { 3 - 4 } & & $\mathrm{R}$ & $\mathrm{X}$ & & \\
\hline 1 & 1 & $\mathrm{Me}$ & $\mathrm{I}$ & 5 & 98 \\
2 & 2 & $\mathrm{MeO}$ & $\mathrm{Br}$ & 20 & 96 \\
3 & 3 & $\mathrm{MeO}$ & $\mathrm{Br}$ & 20 & 94 \\
4 & 4 & $\mathrm{MeO}$ & $\mathrm{Br}$ & 20 & 95 \\
5 & 1 & $\mathrm{C}(\mathrm{O}) \mathrm{Me}$ & $\mathrm{Cl}$ & 60 & 95 \\
6 & 2 & $\mathrm{C}(\mathrm{O}) \mathrm{Me}$ & $\mathrm{Cl}$ & 60 & 80 \\
7 & 3 & $\mathrm{C}(\mathrm{O}) \mathrm{Me}$ & $\mathrm{Cl}$ & 60 & 68 \\
8 & 4 & $\mathrm{C}(\mathrm{O}) \mathrm{Me}$ & $\mathrm{Cl}$ & 60 & 49 \\
\hline
\end{tabular}

aReaction conditions: $0.5 \mathrm{mmol}$ aryl halide, $0.55 \mathrm{mmol}$ phenylboronic acid, $1.0 \mathrm{mmol} \mathrm{Cs} \mathrm{CO}_{3}$, starting concentration of catalyst 9 (series 1, entries 1-4; series 2, entries 5-8) $0.2 \mathrm{~mol} \%, 2 \mathrm{ml}$ toluene, $200 \mathrm{~W}$ microwave heating (fixed power).

betermined by GC analysis with diethylene glycol-di- $n$-butyl ether as internal standard.

was reused in subsequent runs without apparent loss of activity (Table 1, series 1: entries 1-6; series 2: entries 7-11). Monitoring the conversion versus time for the reaction of 4-bromoanisole and phenylboronic acid (Figure 2) revealed that the reaction reached $50 \%$ conversion after $1 \mathrm{~h}$ and $80 \%$ conversion after $2 \mathrm{~h}$.

Carrying out Suzuki-Miyaura couplings under microwave irradiation (Table 2) in closed vessel conditions at $140^{\circ} \mathrm{C}$ not only greatly shortened the reaction times but also allowed the

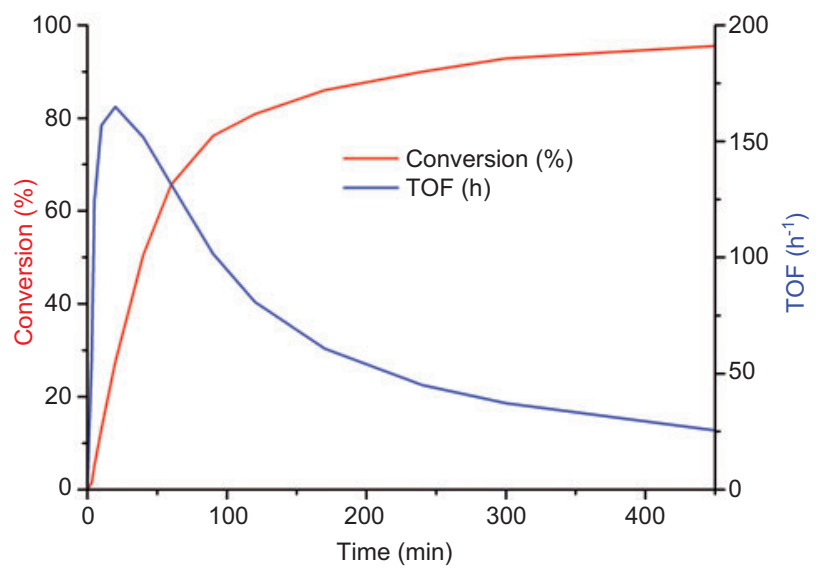

Figure 2 Time conversion and time-turn-over frequency (TOF) curves of $9(0.2 \mathrm{~mol} \%)$ in the Suzuki-Miyaura cross-coupling reaction between bromobenzene and phenylboronic acid.

coupling of less reactive aryl chlorides. Again, 9 was readily recycled by an external magnet and reused; nevertheless, we noted a significant drop of activity in the coupling of aryl chlorides with each cycle. TEM analysis revealed the formation of palladium nanoparticles over time and reaction cycles that apparently became trapped in the polystyrene matrix, i.e. indicating the decomposition palladium complex in 9. This breakdown occurred under microwave conditions $\left(140^{\circ} \mathrm{C}\right)$ but to our surprise also under thermal conditions at $70^{\circ} \mathrm{C}$ (Figure 3 ). It should be noted that ICP-OES measurements revealed, in all cases (Tables 1 and 2), that $<2$ ppm palladium in each cycle was released into the reaction solution. Because the number but not the size of the nanoparticles was increasing with the<smiles>Oc1cc(CBr)cc(CBr)c1</smiles>

3<smiles>Cc1cc(C)c(-n2cc[nH+]c2)c(C)c1</smiles>

4

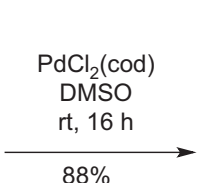

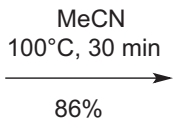

$86 \%$

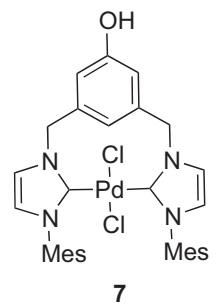<smiles></smiles>

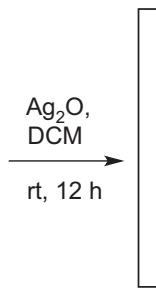<smiles>[Y6]C1N(C)C=CN1Cc1cc(O)cc(CN2CCN(C)C2[14CH3])c1</smiles>

6
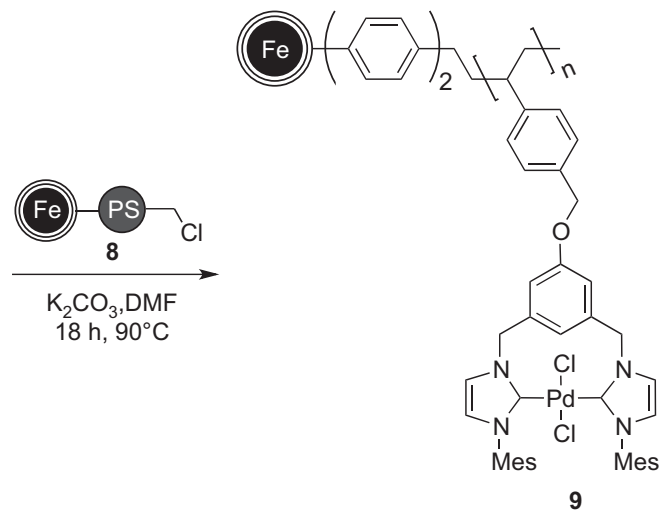

Scheme 1 Synthesis of polystyrene modified, carbon coated iron nanoparticle supported palladium complex 9. 

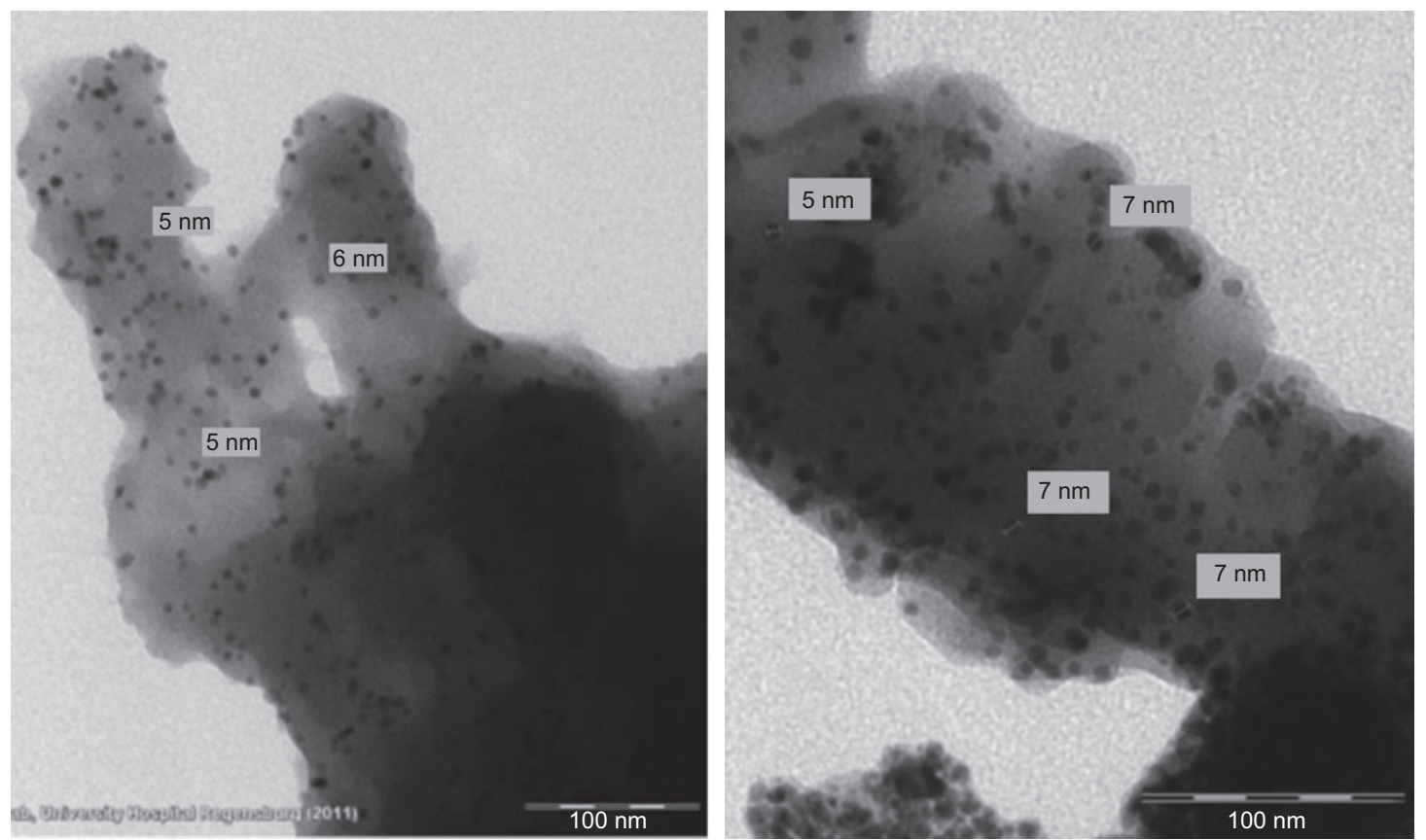

Figure 3 Representative TEM micrographs of 9 after heating under conventional heating taken after one (left) and four (right) reaction cycles (for conditions see Table 1, entries 1-4). Palladium nanoparticles (5-7 nm) are formed that are encapsulated in the polystyrene matrix (upper left part in each image) that is attached to the carbon coated iron particle $(20-50 \mathrm{~nm}$, lower right part in each image).

reaction cycles performed, it is assumed that these palladium nanoparticles do not leach to a significant extent from the polystyrene matrix as opposed to being trapped in there upon cooling the reaction mixture. Although this finding might open up an interesting strategy for nanoparticle synthesis in a polymer matrix that is, in return, attached to magnetic nanoparticles, we must conclude for our current study that the palladium nanoparticles formed do not exhibit the same, if any, catalytic activity for the Suzuki-Miyaura cross-coupling.

In conclusion, the immobilization of palladium NHC complex $\mathbf{7}$ to iron nanoparticles $\mathbf{8}$ resulted in a magnetically recyclable catalyst $\mathbf{9}$ that was successfully employed in SuzukiMiyaura coupling reactions of aryl halides. In particular, it was shown that under microwave irradiation, even aryl chlorides can be employed as substrates. As a possible pathway for catalyst deactivation, the formation of palladium nanoparticles was identified that are encapsulated into the polystyrene matrix of the support.

\section{Acknowledgments}

This work was supported by the Deutsche Forschungsgemeinschaft and ANR (Re 948/8-1, "GLOBUCAT") and the IDK NANOCAT (Elitenetzwerk Bayern).

\section{References}

[1] Benaglia M, Ed., Recoverable and Recyclable Catalysts, John Wiley \& Sons, Ltd.: New York, 2009.
[2] Shylesh S, Schünemann V, Thiel WR. Angew. Chem. Int. Ed. 2010, 49, 3428-3459.

[3] Schätz A, Reiser O, Stark WJ. Chem. Eur. J. 2010, 16, 8950-8967.

[4] Polshettiwar V, Luque R, Fihri A, Zhu H, Bouhrara M, Basset J-M. Chem. Rev. 2011, 111, 3036-3075.

[5] Grass RN, Athanassiou EK, Stark WJ. Angew. Chem. Int. Ed. 2007, 46, 4909-4912.

[6] Schätz A, Grass RN, Stark WJ, Reiser O. Chem. Eur. J. 2008, $14,8262-8266$.

[7] Schätz A, Grass RN, Kainz Q, Stark WJ, Reiser O. Chem. Mater. 2010, 22, 305-310.

[8] Wittmann S, Schätz A, Grass RN, Stark WJ, Reiser O. Angew. Chem. Int. Ed. 2010, 49, 1867-1870.

[9] Schätz A, Long TR, Grass RN, Stark WJ, Hanson PR, Reiser O. Adv. Funct. Mater. 2010, 20, 4323-4328.

[10] Maity PK, Kainz QM, Faisal S, Rolfe A, Samarakoon TB, Basha FZ, Reiser O, Hanson PR. Chem. Commun 2011, 47, 12524.

[11] Maity PK, Rolfe A, Samarakoon TB, Faisal S, Kurtz RD, Long TR, Schätz A, Flynn DL, Grass RN, Stark WJ, Reiser O, Hanson PR. Org. Lett. 2011, 13, 8-10.

[12] Herrmann WA, Köcher C. Angew. Chem. Int. Ed. 1997, 36, 2162-2187.

[13] Kang T, Feng Q, Luo M. Synlett 2005, 2305-2308.

[14] Jokic NB, Straubinger CS, Goh SLM, Herdtweck E, Herrmann WA, Kühn FE. Inorg. Chim. Acta 2010, 363, 4181-4188.

[15] Magill AM, McGuinness DS, Cavell KJ, Britovsek GJP, Gibson VC, White AJP, Williams DJ, White AH, Skelton BW. $J$. Organomet. Chem. 2001, 617-618, 546-560. 
[16] Ronde NJ, Totev D, Müller C, Lutz M, Spek AL, Vogt D. Chem. Sus. Chem. 2009, 2, 558-574.

[17] Occhipinti G, Bjørsvik HR, Törnroos KW, Fürstner A, Jensen VR. Organometallics 2007, 26, 4383-4385.

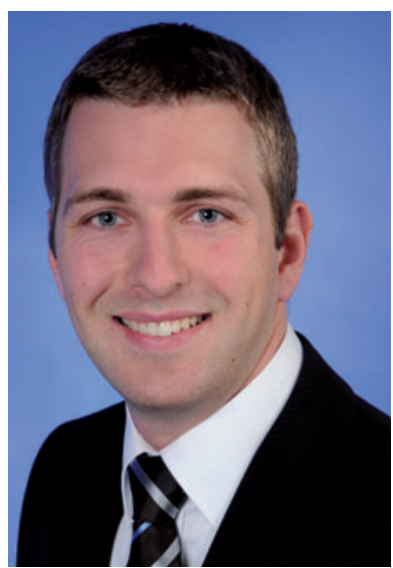

Sebastian Wittmann studied Chemistry at the University of Regensburg and completed his $\mathrm{PhD}$ in 2012 in Prof. Reiser's group. He is a member of the International Graduate School NANOCAT of the Elitenetzwerk Bavaria, Germany.

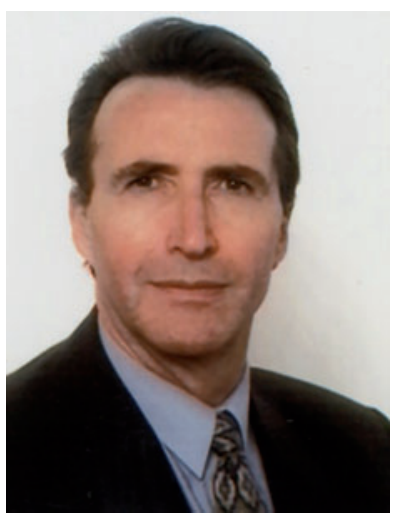

Jean-Pierre Majoral is an Emeritus Director of Researches Exceptional Class at CNRS. After his $\mathrm{PhD}$, he worked as a postdoc with A. Katritzky (Norwich, UK). He became the Director of Research at CNRS in 1978. He was in charge of the French-Polish European Institute (LEA, 2000-2008). His research interest is mainly focused on main group elements, especially phosphorus in different areas of chemistry. Presently, he is involved in the preparation and properties of dendrimers and hyperbranched polymers with emphasis on their applications in different fields ranging from biology, nanomaterials and catalysis. He is a member of several academies of science worldwide and has received various international awards. He is the author of approximately 500 publications and 40 patents.

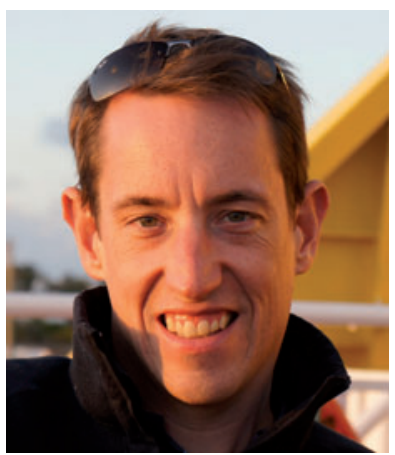

Robert Grass is a Senior Scientist at ETH Zurich, Switzerland. He studied Chemical Engineering at ETH Zurich where he also completed his $\mathrm{PhD}$ in the Prof. Stark's group in 2007. Robert is a co-founder and CEO of TurboBeads Llc, a spin-off company commercializing magnetic nanobeads.
[18] Schätz A, Zeltner M, Michl TD, Rossier M, Fuhrer R, Stark WJ. Chem. Eur. J. 2011, 17, 10566-10573.

Received April 29, 2012; accepted May 4, 2012

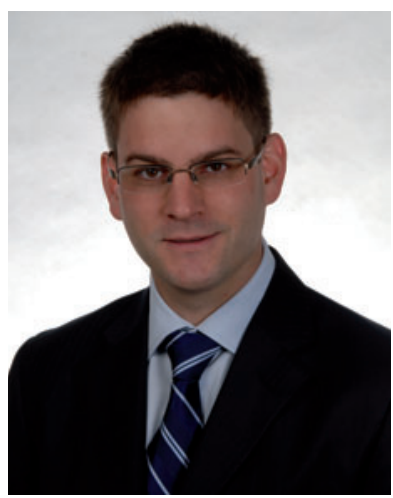

Wendelin J. Stark received his Master's in Chemistry in 2000 followed by a $\mathrm{PhD}$ in Mechanical Engineering in 2002 from ETH Zurich, Switzerland. He founded the Functional Materials Laboratory in 2004 and pursues application-oriented research at the interface of chemistry with material science and medicine. He has co-founded four spin-off companies and authored over 150 papers and 20 patents.

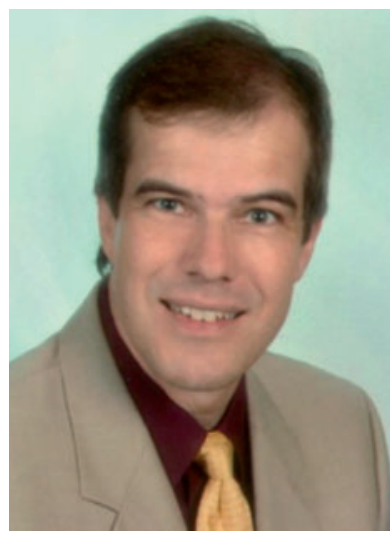

Oliver Reiser is Professor of Organic Chemistry at the University of Regensburg. After his $\mathrm{PhD}$ at the University of Hamburg (A. de Meijere), he worked as a postdoc at the IBM Research Center, San Jose, CA, USA (R.D. Miller) and at Harvard University, Boston, MA, USA (D.A. Evans). Having started his independent academic career as an assistant professor at the University of Göttingen (1992-1996), he became associate professor at the University of Stuttgart (1997) before he moved to his current position at Regensburg. His research interests are centered around stereoselective synthesis and catalysis, natural products and peptide foldamers. He is the author of approximately 200 publications. 